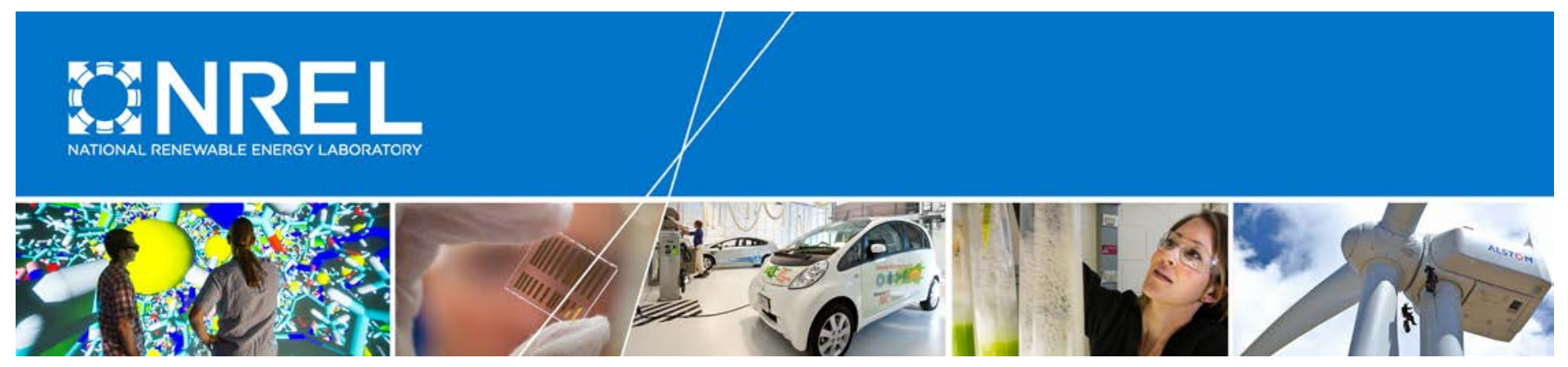

\title{
Potential Avenues for Significant Biofuels Penetration in the U.S. Aviation Market
}

Emily Newes

National Renewable Energy Laboratory

Jeongwoo Han

Argonne National Laboratory

Steve Peterson

Lexidyne LLC

NREL is a national laboratory of the U.S. Department of Energy Office of Energy Efficiency \& Renewable Energy Operated by the Alliance for Sustainable Energy, LLC

This report is available at no cost from the National Renewable Energy Laboratory (NREL) at www.nrel.gov/publications.

Technical Report

NREL/TP-6A20-67482

April 2017

Contract No. DE-AC36-08G028308 


\section{Potential Avenues for} Significant Biofuels Penetration in the U.S. Aviation Market

Emily Newes

National Renewable Energy Laboratory

Jeongwoo Han

Argonne National Laboratory

Steve Peterson

Lexidyne LLC

Prepared under Task No. BZ14.3003
NREL is a national laboratory of the U.S. Department of Energy Office of Energy Efficiency \& Renewable Energy Operated by the Alliance for Sustainable Energy, LLC

This report is available at no cost from the National Renewable Energy Laboratory (NREL) at www.nrel.gov/publications.

\section{Technical Report}

NREL/TP-6A20-67482

April 2017

Contract No. DE-AC36-08G028308
National Renewable Energy Laboratory 15013 Denver West Parkway

Golden, CO 80401

303-275-3000 • www.nrel.gov 


\section{NOTICE}

This report was prepared as an account of work sponsored by an agency of the United States government. Neither the United States government nor any agency thereof, nor any of their employees, makes any warranty, express or implied, or assumes any legal liability or responsibility for the accuracy, completeness, or usefulness of any information, apparatus, product, or process disclosed, or represents that its use would not infringe privately owned rights. Reference herein to any specific commercial product, process, or service by trade name, trademark, manufacturer, or otherwise does not necessarily constitute or imply its endorsement, recommendation, or favoring by the United States government or any agency thereof. The views and opinions of authors expressed herein do not necessarily state or reflect those of the United States government or any agency thereof.

This report is available at no cost from the National Renewable Energy Laboratory (NREL) at www.nrel.gov/publications.

Available electronically at SciTech Connect http:/www.osti.gov/scitech

Available for a processing fee to U.S. Department of Energy and its contractors, in paper, from:

U.S. Department of Energy

Office of Scientific and Technical Information

P.O. Box 62

Oak Ridge, TN 37831-0062

OSTI http://www.osti.gov

Phone: 865.576.8401

Fax: 865.576.5728

Email: reports@osti.gov

Available for sale to the public, in paper, from:

U.S. Department of Commerce

National Technical Information Service

5301 Shawnee Road

Alexandria, VA 22312

NTIS http://www.ntis.gov

Phone: 800.553 .6847 or 703.605 .6000

Fax: 703.605.6900

Email: orders@ntis.gov 


\section{Acknowledgements}

The authors would like to acknowledge Zia Haq and Alicia Lindauer of the U.S. Department of Energy for their support of analyses of potential biofuels markets. We thank the reviewers, Kristin Lewis (U.S. Department of Transportation); James Hileman and Nathan Brown (U.S. Department of Transportation, Federal Aviation Administration); Steve Csonka (Commercial Aviation Alternative Fuels Initiative); and Ling Tao (National Renewable Energy Laboratory) for their comments on draft versions of the report. 


\section{Executive Summary}

Industry associations and governing bodies have set goals to reduce greenhouse gas (GHG) emissions and increase fuel efficiency in the aviation sector. The use of aviation biofuel is a focal area for reducing GHG emissions. This study examines the following question: is it possible to displace $30 \%$ of projected national annual jet fuel demand (approximately six billion gallons of the 2015 domestic U.S. market) with biofuels by 2030 ? We find that it is possible under aggressive policy and/or investment scenarios (Figure ES1), but several factors related to policy design - in the absence of high oil prices or policy uncertainty — contribute to the timing and magnitude of aviation biofuels production:

- Incentives targeted toward jet fuel production, such as financial incentives (e.g., a producer tax credit or a carbon tax) could be sufficient to reach six billion gallons.

- Investment in pre-commercial technologies is needed to reduce the cost of production through learning-by-doing.

- Reduction of investment risk through loan guarantees and offtake agreements may allow production to ramp up more quickly through accelerating industry learning.

In cases with high levels of incentives and investment in aviation biofuels, there could be up to a $25 \%$ reduction in overall GHG emissions from the aviation sector.

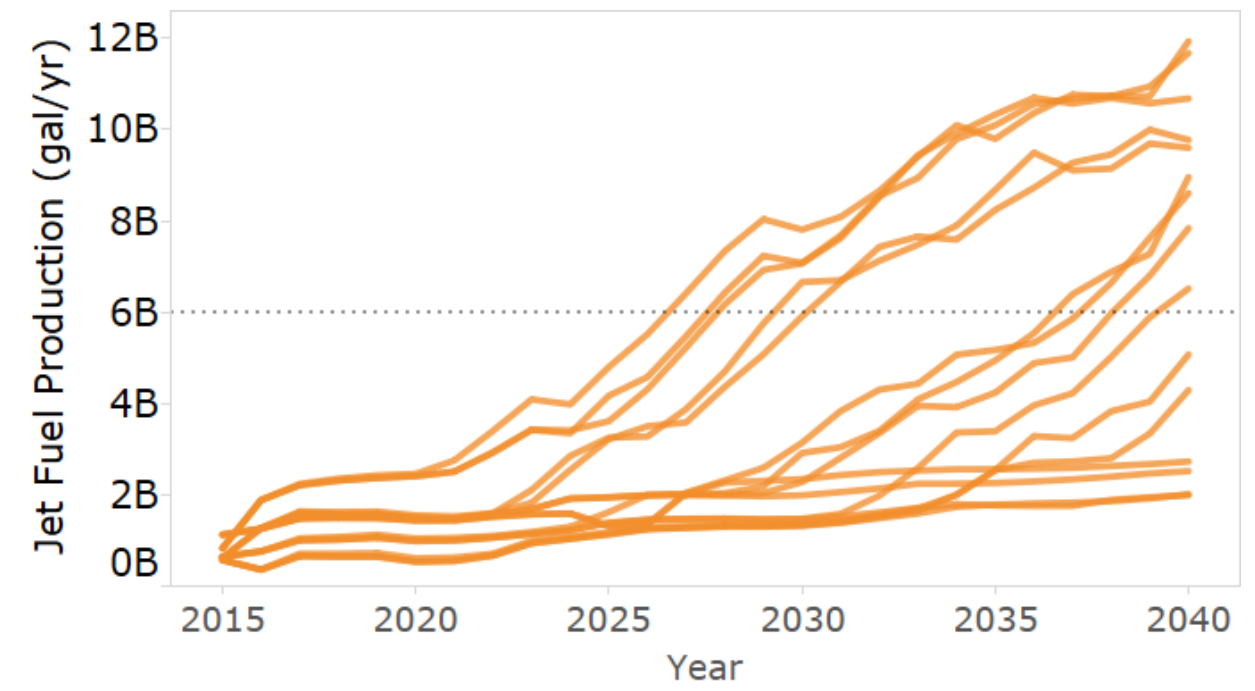

Figure ES1. Trajectories of total aviation biofuel production under different scenarios presented in this article 


\section{Table of Contents}

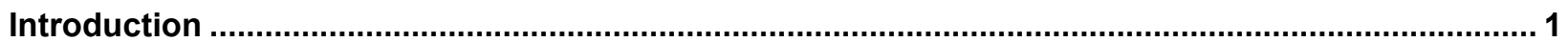

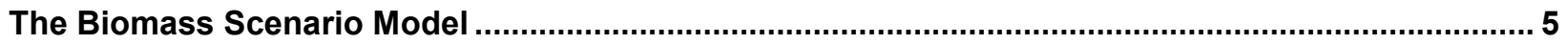

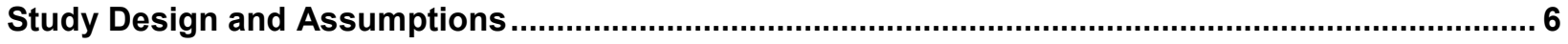

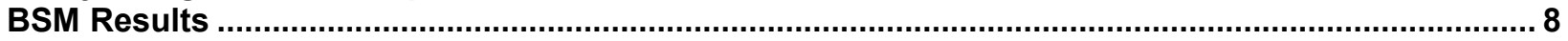

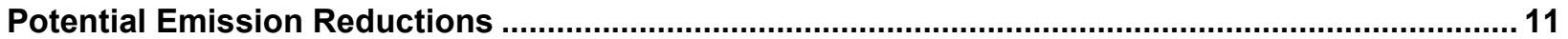

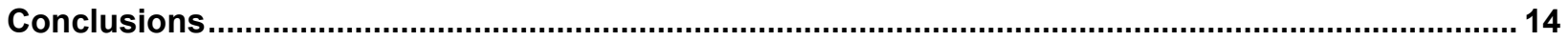

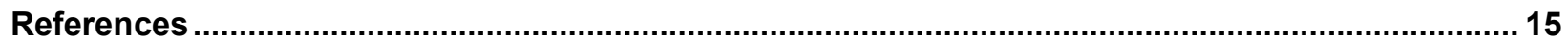

\section{List of Figures}

Figure ES1. Trajectories of total aviation biofuel production under different scenarios presented in this article.

Figure 1. Notional industry trends for global emissions from aviation under different scenarios .... 1

Figure 2. Passenger-miles traveled (pink) and jet fuel consumption (gray), 1994-2014................... 2

Figure 3. Aviation biofuels production under different public/private investment scenarios (rows)

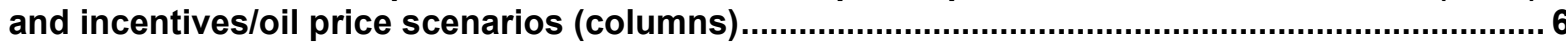

Figure 4. Cellulosic feedstock production (left) and oil supply (right) for all biofuels in the case with a $\$ 60 /$ tonne carbon tax and a $\$ 1 /$ gal production incentive for jet fuel in addition to DMT investment and eight offtake agreements (see panel $[\mathrm{m}]$ in Figure 3 ).

Figure 5. Finished fuel production in the case with a $\$ 60 /$ tonne carbon tax and a $\$ 1 /$ gal production incentive for jet fuel in addition to DMT investment and eight offtake agreements (see panel [m] in Figure 3)

Figure 6. GHG emissions changes by renewable fuels in million tonnes $\mathrm{CO}_{2} \mathrm{e} / y e a r$ with DMT investment and eight offtake agreements relative to the reference scenario (the baseline scenario with no offtake agreements of DMT investment) (Figure 3, Row 3 compared with panel [a])

Figure 7. GHG emissions changes by ATJ, HEFA, and FTJ in million tonnes $\mathrm{CO}_{2}$ e/year with DMT investment and eight offtake agreements relative to the reference scenario (the baseline scenario with no offtake agreements of DMT investment) (Figure 3, Row 3 compared with panel [a]).

\section{List of Tables}

Table 1. Aviation Biofuels Conversion Pathways Used in this Analysis ............................................ 3

Table 2. Offtake Agreements for Aviation Biofuel in the United States ......................................... 4 


\section{Introduction}

Fuel price volatility impacts the airline industry, where fuel is the most expensive component of direct operating costs (Carolyn Davidson et al. 2014). Industry associations and governing bodies have set goals to reduce greenhouse gas emissions (GHG) and increase fuel efficiency (Figure 1). Increasing biofuel use in the airline fleet is one means of meeting these goals.

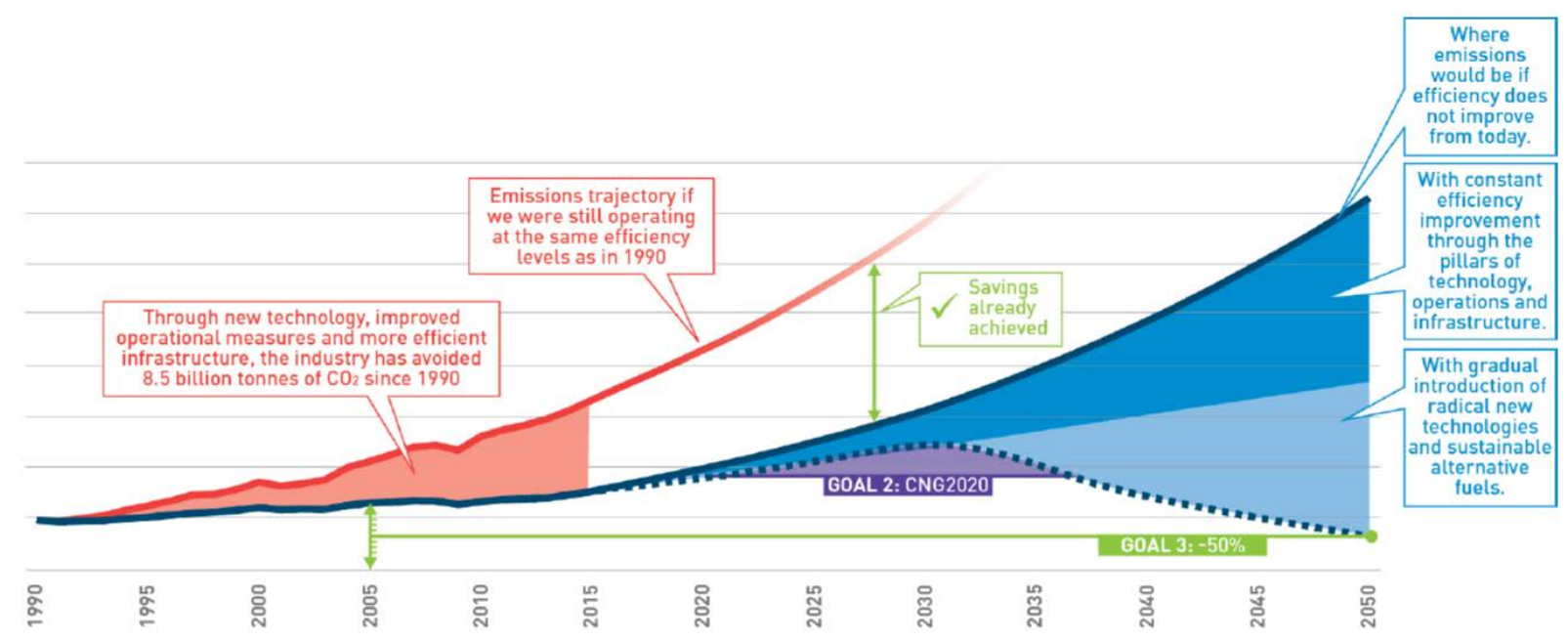

Figure 1. Notional industry trends for global emissions from aviation under different scenarios

Source: Steele 2016

Decision makers need to understand the market conditions that lead to substantial biofuel penetration into the jet fuel market. Constraints and incentives across the biomass-to-biofuels supply chain determine the potential for aviation biofuel production. In this report, we explore different combinations of investment and incentives that could help the aviation biofuel industry reach high levels of penetration in the jet fuel market. Specifically, we perform analyses to answer the following question: is it possible to displace $30 \%$ of projected national annual jet fuel demand (approximately six billion gallons of the 2015 domestic U.S. market) with biofuels by 2030 ?

The U.S. airline industry has been improving efficiency across their operations with the goals of decreasing costs and benefitting the environment. For example, the consumption of jet fuel in the United States has been slightly declining over the past 20 years, while the passenger miles traveled has been steadily increasing over the same period (Figure 2). 


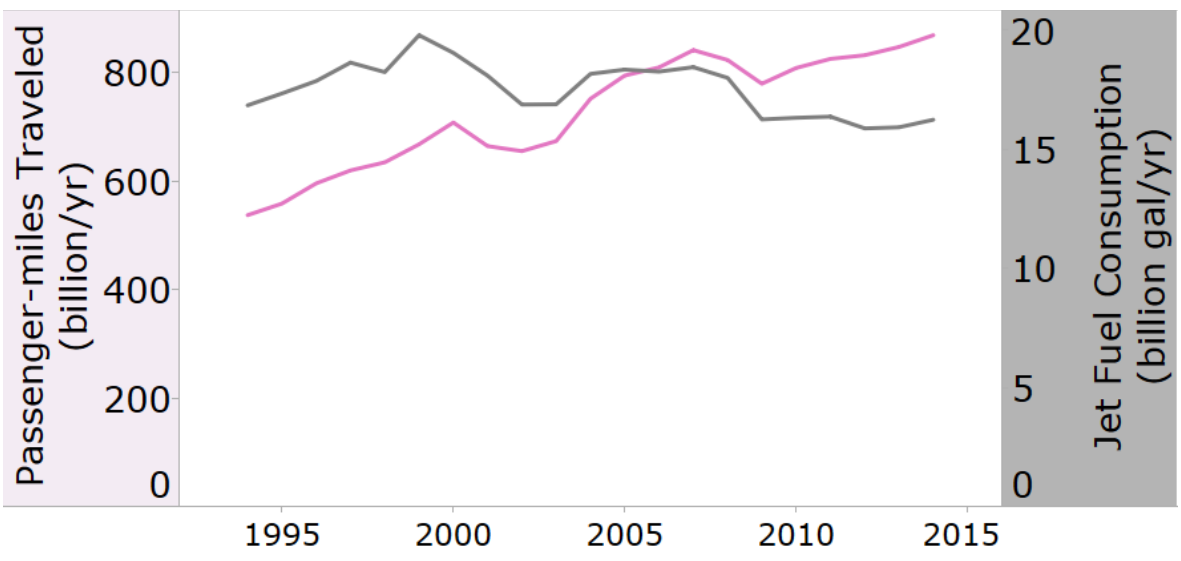

Figure 2. Passenger-miles traveled (pink) and jet fuel consumption (gray), 1994-2014

Source: Bureau of Transportation Statistics 2015

In 2008, the international aviation community committed to reducing carbon emissions, with goals to improve fuel efficiency, cap carbon dioxide emissions at 2020 levels, and accomplish a $50 \%$ decrease (from 2005 levels) in net carbon dioxide emissions by 2050 (Air Transport Action Group 2010). These efforts were bolstered in 2016 when governments and industry agreed on the Carbon Offsetting and Reduction Scheme for International Aviation at the International Civil Aviation Organization's 39 ${ }^{\text {th }}$ Assembly (International Civil Aviation Organization 2016b). The new regulations will be phased in from 2021 to 2035, and they will be piloted by countries that account for over $80 \%$ of air traffic (International Civil Aviation Organization 2016a). The Air Transport Action Group has laid out strategies for meeting these goals; for the 50\% reduction in $\mathrm{CO} 2$ emissions by 2050, the two main strategies are 1) continuing to pursue improvements from operations, infrastructure, and technology incorporation (including engine and airframe improvements) and 2) using sustainable alternative fuel while continuing to explore radical new technologies (Air Transport Action Group 2015). In addition, a recent analysis by the National Academy of Sciences, Engineering, and Medicine (2016) recommended advancing sustainable aviation biofuels as one of four strategies for reducing GHG emissions in the aviation sector. The purpose of this study is to explore conditions under which the United States could see large production in aviation biofuel to help in reaching this emission reduction goal.

For this study, we assessed aviation biofuels pathways that are in the certification process and have available techno-economic estimates. ${ }^{1}$ Table 1 shows the biomass-to-aviation-biofuels pathways that were part of our analysis, along with their stages of ASTM certification. The ultimate mature technology prices for the pathways in Table 1 range from $\$ 3.30 /$ gal to $\$ 5.4 /$ gal (Pearlson, Wollersheim, and Hileman 2013; UOP 2008; Davis et al. 2015; Davis et al. 2013; Wang et al. 2016; Tan et al. 2016).

\footnotetext{
${ }^{1}$ Our analysis included other conversion pathways that were assumed to produce fuels other than aviation biofuel. These pathways include fast pyrolysis, methanol to gasoline, thermochemical ethanol, biochemical ethanol, and algal pathways.
} 
Table 1. Aviation Biofuels Conversion Pathways Used in this Analysis*

\begin{tabular}{lll}
\hline Conversion Process & Feedstock & Stage of ASTM Certification \\
\hline $\begin{array}{l}\text { Hydro-processed esters and fatty } \\
\text { acids (HEFA) }\end{array}$ & $\begin{array}{l}\text { Waste fats, oils, and } \\
\text { greases and oil-seed crops }\end{array}$ & Approved \\
\hline $\begin{array}{l}\text { Gasification followed by Fischer- } \\
\text { Tropsch (FTJ) conversion }\end{array}$ & $\begin{array}{l}\text { Coal or biomass, primarily } \\
\text { woody feedstocks, biogas, } \\
\text { municipal solid waste }\end{array}$ & Approved \\
\hline $\begin{array}{l}\text { Direct sugars to hydrocarbons: } \\
\text { biochemical conversion of sugars to } \\
\text { farnasane as a blending component of } \\
\text { jet fuel }\end{array}$ & $\begin{array}{l}\text { Sugars, including } \\
\text { herbaceous feedstocks }\end{array}$ & Approved \\
\hline $\begin{array}{l}\text { Alcohol to Jet (ATJ): thermochemical } \\
\text { conversion of alcohols to jet via } \\
\text { dehydration, oligomerization, and } \\
\text { hydroprocessing }\end{array}$ & $\begin{array}{l}\text { C2-C5 alcohols derived } \\
\text { from any source including } \\
\text { sugars from any feedstock } \\
\text { and those derived from } \\
\text { lignocellulose }\end{array}$ & Approved in 2016 for isobutanol \\
\hline Catalytic Hydrothermolysis & $\begin{array}{l}\text { Waste fats, oils, greases } \\
\text { and purpose grown lipids }\end{array}$ & Expected in 2017 \\
\hline $\begin{array}{l}\text { Catalytic and fermentative upgrading } \\
\text { of sugars }\end{array}$ & \begin{tabular}{l} 
Herbaceous feedstocks \\
\hline
\end{tabular} & Long-term \\
\hline
\end{tabular}

These pathways were modeled but not all had appreciable production levels.

*Many additional fuels are being examined for ASTM approval and these new pathways will have economics that are different from those listed in Table 2 in terms of product slate, production potential, feedstock usage, and economics of production.

** (Gevo Inc 2016a) Approval expected to be expanded to include any C2-C5 alcohol as such processes are demonstrated by additional producers (e.g. LanzaTech in 2018).

As of 2015, aviation biofuel had been used in over 2,000 commercial flights by more than 20 airlines (Air Transport Action Group 2015); however, the cost of aviation biofuels is still substantially higher than conventional petroleum-based jet fuel. Commercial airlines and the U.S. government have been investing in aviation biofuel-producing technologies to aid them in transitioning to commercial production levels. Numerous airlines have signed long-term offtake agreements for up to ten years (Table 2). 
Table 2. Offtake Agreements for Aviation Biofuel in the United States

\begin{tabular}{llrllll}
\hline Purchaser & Supplier & Mass [t/yr] & $\begin{array}{l}\text { Feedstock } / \\
\text { product }\end{array}$ & $\begin{array}{l}\text { Duration } \\
\text { (years) }\end{array}$ & $\begin{array}{l}\text { Start of } \\
\text { Delivery }\end{array}$ & $\begin{array}{l}\text { Contract } \\
\text { Date }\end{array}$ \\
\hline GE Aviation & D'Arcinoff & 17,000 & Cellulosic biomass & 10 & - & 2013 \\
\hline United & Altair & 17,000 & $\begin{array}{l}\text { Waste fats, oils, } \\
\text { and greases }\end{array}$ & 3 & 2016 & 2013 \\
\hline Gulfstream & World Fuel & & Waste fats, oils, & 3 & 2016 & 2015 \\
& $\begin{array}{l}\text { Services } \\
\text { (Altair) }\end{array}$ & unknown & and greases & 3 & 2014 \\
\hline Cathay & Fulcrum & 100,000 & Waste & 10 & 2019 & 2014 \\
\hline FedEx/ & Red Rock & 10,000 & Forest residues & 8 & 2017 & 2015 \\
\hline Southwest & Fulcrum & $270,000+$ & Waste & 10 & 2019 & 2016 \\
\hline KLM & Altair & unknown & Used cooking oil & 3 & - & $2016^{*}$ \\
\hline Lufthansa & Gevo & $270,000+$ & Wood & & \\
\hline JetBlue & S.G. Preston & 33,500 & waste/Alcohol to jet & 5 & - & 2016 \\
\hline
\end{tabular}

${ }^{*}$ Date of memorandum of understanding

Sources: International Air Transport Association 2016; GE Aviation 2013; Gevo Inc 2016b; KLM 2016;

Schlangenstein 2016; Gulfstream Corporation 2015

The U.S. military has also contributed to aviation biofuels development (Carolyn Davidson et al. 2014). Through the Defense Production Act, the U.S. Department of Defense, in collaboration with the U.S. Department of Energy (DOE), and the U.S. Department of Agriculture, awarded funding to three biorefineries in 2014 (Lane 2014). The U.S. Federal Aviation Administration (FAA) founded a Center of Excellence for Alternate Jet Fuels and the Environment (the Aviation Sustainability Center [ASCENT]) in 2013, which is being led by Washington State University and the Massachusetts Institute of Technology, and the FAA is looking at how to tackle some of the industry's most pressing issues (U.S. Federal Aviation Administration 2013). The Federal Alternative Jet Fuel Research and Development Strategy was released in July 2016 and offers a strategy for better coordination and strategic goals for federal research and development that would address key challenges to deployment of aviation biofuels (Aeronautics Science and Technology Subcommittee 2016). 


\section{The Biomass Scenario Model}

The DOE Bioenergy Technologies Office and the National Renewable Energy Laboratory developed the Biomass Scenario Model (BSM) to investigate the potential dynamics associated with the evolution of a biofuel industry in the United States (Bush 2015). The model uses a system dynamics modeling approach, and is built on the STELLA software platform (isee systems 2016), to represent the dynamic interactions of the major stages of the biomass-tobiofuel supply chain - feedstock production and logistics, feedstock conversion, and downstream elements (inventory, distribution, dispensing, fuel use, and vehicle fleet). The BSM tracks the development of the biofuel industry over time by representing investment in new technologies, competition from petroleum fuels, vehicle demand for biofuels, and implementation of various government policies. As an established methodology for analyzing the behavior of complex, feedback-rich systems, system dynamics focuses on the relationships between and feedback among parts of a system and can facilitate investigation of system bottlenecks, analysis of policies, and diagnosis of unintended consequences (Sterman, Morrison, and Repenning 2003). Extensive analyse ${ }^{2}$ have been performed using the model to address the critical role played by system bottlenecks, gasoline pricing, industrial learning, and financing in development of the biofuel industry.

The BSM is designed to be modular, such that each major component (feedstock supply and logistics, feedstock conversion, and downstream) can be simulated in isolation from or in conjunction with other sectors. The feedstock production and logistics sector in the model simulates the production of bioenergy and commodity crops, through farmer decision-making, land allocation dynamics, and new agricultural practices, markets, and prices; it also tracks costs associated with harvesting, collection, storage, preprocessing, and transportation of feedstocks. The feedstock conversion modules capture investment and operation of various conversion pathways, including algae, oil crops, renewable hydrocarbons, starch ethanol, and cellulosic ethanol. The model represents 15 conversion platforms at three production scales. These platforms convert feedstock into distinct product tracks including ethanol, butanol, and hydrocarbons (jet fuel, gasoline, and diesel). The model is geographically stratified, using the 10 U.S. Department of Agriculture farm production regions (National Resources Conservation Service 2016), which allows region-specific analyses to be performed.

\footnotetext{
${ }^{2}$ For example, see (Newes, Inman, and Bush 2011; Newes et al. 2015; Clark et al. 2013; Vimmerstedt, Bush, and Peterson 2012; Vimmerstedt, Bush, and Peterson 2013; Vimmerstedt, Warner, and Stright 2016; Vimmerstedt et al. 2015).
} 


\section{Study Design and Assumptions}

This study uses model simulations to explore how combinations of incentives and public/private investment could impact industrial output of aviation biofuels (Figure 3). For the baseline incentive case (Figure 3, Column A), the following conditions are applied:

- $\$ 0.70 /$ renewable identification number (RIN), held constant for the entire simulation

- Annual Energy Outlook (AEO) 2015 Reference Oil Price (Energy Information Administration 2015)

- Tax credit extension for first one billion gallons of cumulative production by conversion pathway group (e.g., cellulose to hydrocarbon)

- $80 \%$ loan guarantee for first 250 million gallons of cumulative production by conversion pathway (e.g., oil to hydrocarbon)

- For each of the aviation biofuels pathways, refined fuel mix is treated as an input so jet fuel production is maximized and not dynamically determined based on relative prices and other factors

- Biorefinery construction is assumed to be limited to a maximum of 25 plants per year, due to labor and materials constraints (Warner 2014).

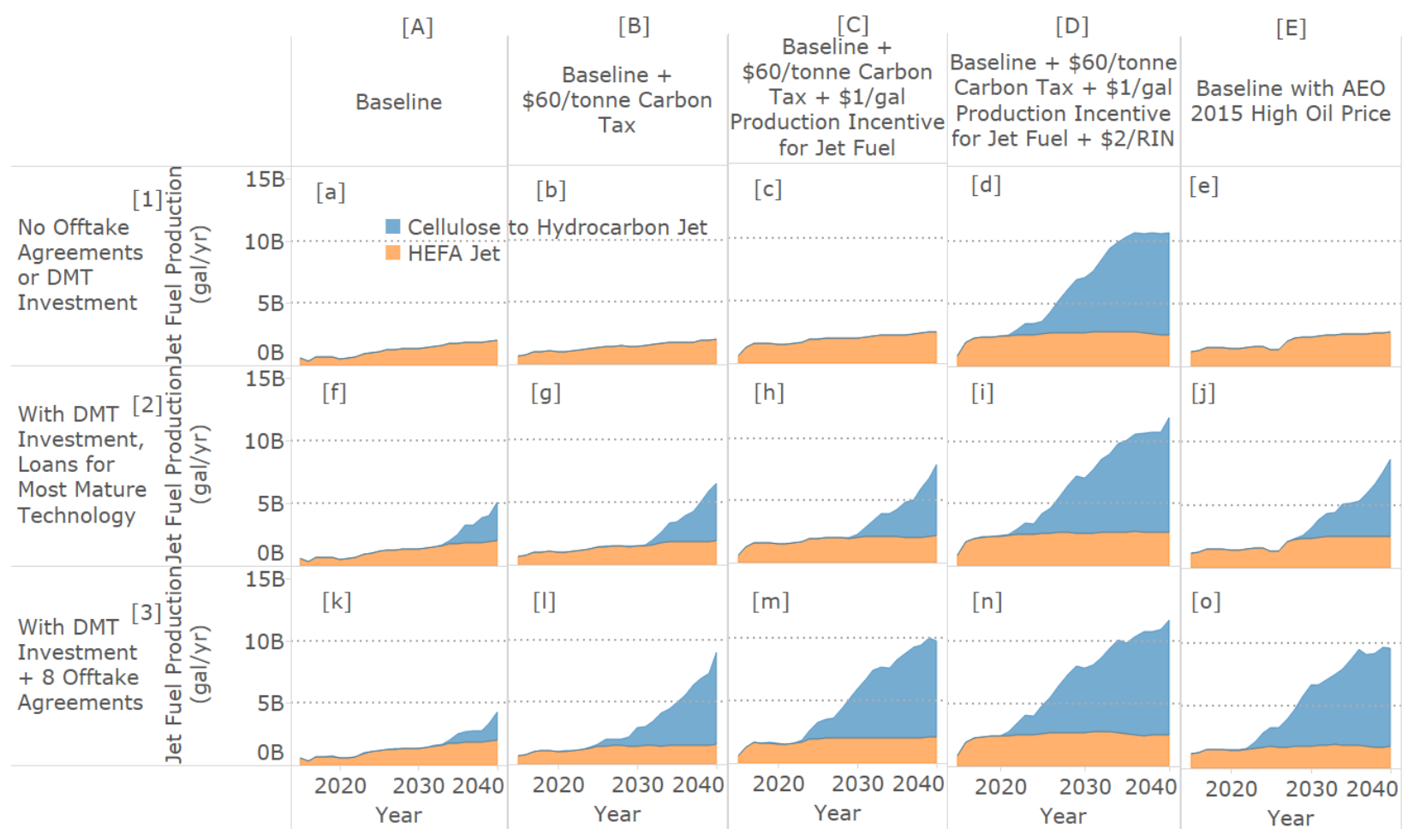

Figure 3. Aviation biofuels production under different public/private investment scenarios (rows) and incentives/oil price scenarios (columns) 
The baseline investment scenario is represented by the title "No Offtake Agreements or Demonstration and Market Transformation (DMT) Investment" (Figure 3, Row 1). The only facilities that are assumed in this scenario are those that already exist or are already under construction, as of 2015 (Schwab, Warner, and Lewis 2016). The investment scenario with DMT investment build on this case with assumptions about public investment in pre-commercial facilities that lead to loan guarantees for three commercial ${ }^{3}$ biorefineries (Figure 3, Row 2). The investment is modeled in a similar way to Vimmerstedt et al. (2016), but all investment is geared toward aviation biofuels technologies. The investment scenario with eight offtake agreements assumes that eight commercial facilities will be constructed in order to satisfy an agreement to purchase the aviation biofuels (Figure 3, Row 3). ${ }^{4}$ The scenario includes four announced agreements (Haq 2015), including two with Defense Production Act facilities and four theoretical agreements with aviation biofuels facilities that are in the planning stage (one with a Defense Production Act facility). The three different investment scenarios are then combined with five cases, including four with different incentive profiles and one with a higher oil price:

1. No additional incentives beyond the baseline case (Figure 3, Column A)

2. A carbon tax of $\$ 60 /$ tonne in addition to the baseline case incentives; where a carbon tax is present, it is represented as an advantage based on relative carbon intensity versus petroleum (Figure 3, Column B). ${ }^{5}$

3. A production incentive ${ }^{6}$ in addition to the carbon tax and baseline case incentives (Figure 3, Column C); the $\$ 1 /$ gallon production incentive is only applied to jet fuel and "sunsets" in 2030.

4. A high RIN price (\$2/ethanol-equivalent gallon [\$/RIN]) in addition to the jet fuel production incentive, carbon tax, and baseline case incentives (Figure 3, Column D)

5. The baseline incentives case using oil prices from AEO 2015 High Oil Price Case (Figure 3, Column E), which shows an oil price of \$250/barrel in 2040 (Energy Information Administration 2015).

In total, there were 15 incentive case/investment scenario combinations in the analysis (Figure 3).

\footnotetext{
${ }^{3}$ For our purposes, commercial refineries are those with capacities of greater than approximately 20 million gallons/year.

${ }^{4}$ The eight offtake agreements are based on some existing contracts from Table 2, and potential contracts that would begin farther in the future. Scenarios that include offtake agreements assume that $100 \%$ of the contracted production will be purchased for the duration of the contract regardless of price. This logic is considered to be very optimistic and may not represent the actual basis of the offtake agreements.

5 Estimated using life cycle emission factors from the Greenhouse Gases Regulated Emissions and Energy use in Transportation model (includes GHG emissions from entire supply chain: feedstocks cultivation/extraction to fuel use).

${ }^{6}$ This incentive could be viewed as a parallel mechanism for the bio-jet community to how the Commodity Credit Corporation supports feedstock [11].
} 


\section{BSM Results}

This section presents the results of our BSM simulations. Although the results highlight current understanding of the biomass-to-biofuels system, they should not be considered predictive.

Overall, our results suggest that production levels of six billion gallons of aviation biofuels per year are achievable (1) under conditions of aggressive (product maximizing) incentives and public/private investment or (2) with investment and a high oil price. Simulation results are presented in Figure 3 (above).

Aviation biofuels production has limited growth under the reference oil price conditions and the absence of incentive and investment support (Figure 3, panel [a]). High oil prices, alone, are sufficient to spur additional aviation biofuels production (Figure 3, panel [e]). Production levels greater than 10 billion gallons per year are achievable with reference oil prices when RIN prices are $\$ 2 / \mathrm{RIN}$ or higher and aggressive incentives are in place (Figure 3, Column D). In these cases, growth in aviation biofuels production is limited by the assumed annual biorefinery construction limits.

Public investment in the aviation biofuels industry has a positive effect on aviation biofuels production. Without public investment (Figure 3, Row 1), aviation biofuels volumes are lower than those estimated in cases with public investment in pre-commercial facilities and loan guarantees for three commercial facilities deploying the most financially attractive technology (Figure 3, Row 2). If private investment (e.g., offtake agreements) is added, the production volumes are even higher (Figure 3, Row 3).

Incentives can help technologies become successful under low oil price regimes, and they can have a synergistic effect when coupled with public and private investments (Figure 3, Columns B-D). With a carbon tax - either with or without a production incentive - in conjunction with both public and private investment (Figure 3, panels $[\mathrm{g}]$ and $[\mathrm{h}]$ ), the takeoff of the industry is accelerated by 5-7 years in comparison with public investment alone (Figure 3, panels [1] and $[\mathrm{m}])$. This acceleration leads to a $15 \%-30 \%$ increase in production by 2040 . In the case where the world market returns to consistently high oil prices, aviation biofuels can more effectively compete with petroleum-based jet fuel without incentives, as long as investment exists (Figure 3, panels [j] and [o]).

This study assumes that $100 \%$ of the HEFA output can be processed as jet fuel, whereas only around $70 \%$ of the cellulose to hydrocarbon pathways is processed as jet fuel. The work of Pearlson et al. (2013) shows that jet fuel may comprise a much smaller fraction of the product slate since diesel users can also use HEFA products. An additional scenario was explored where a more modest $60 \%$ of HEFA output would be jet fuel. All of the simulations were rerun with this updated assumption, but the overall aviation biofuel production was not greatly impacted. For the scenarios with the greatest production of aviation biofuel (Figure 3, Row 3), overall production was decreased by up to $4 \%$ in 2040 when the ASCENT assumption was used, in comparison with our baseline assumption. However, in cases where there was a production incentive for aviation biofuel (Figure 3, panels [m] and [n]), overall production was not impacted in 2040 . 
Rapid growth of the biofuels industry could put pressure on the feedstock supply and logistics system (Figure 4), both in terms of supply for the oil feedstocks and price for the cellulosic feedstocks. Supply of fats, oils, and greases is constrained by availability of feedstocks, and soybean oil is assumed to be constrained to account for sustainability considerations. ${ }^{7}$ Woody feedstocks are relatively plentiful. However, as the demand for them increases, so does the price; higher prices could make other conversion processes that consume woody feedstocks noncompetitive. Herbaceous feedstocks primarily feed cellulosic biochemical ethanol production. ${ }^{8}$

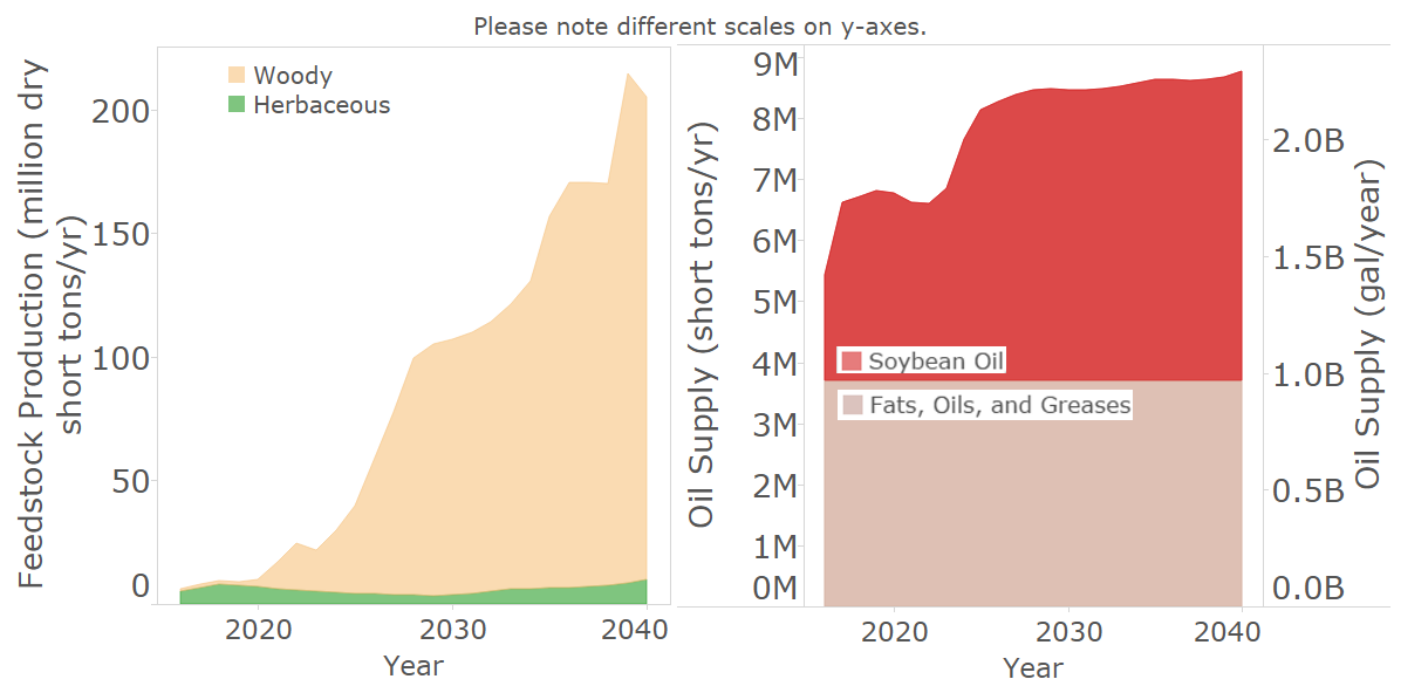

Figure 4. Cellulosic feedstock production (left) and oil supply (right) for all biofuels in the case with a $\$ 60 /$ tonne carbon tax and a $\$ 1 /$ gal production incentive for jet fuel in addition to DMT investment and eight offtake agreements (see panel $[\mathrm{m}]$ in Figure 3 )

These simulations maximized jet fuel production, ${ }^{9}$ but most conversion pathways also produced renewable gasoline and diesel (Figure 5). This result differs from real-world biorefinery behavior in which the mix of products produced is determined in part by profitability considerations. It is unclear how renewable diesel and aviation biofuels would compete in the current or future environment of regulations (e.g., California's Low Carbon Fuel Standard and the Renewable Fuel Standard), potential investment (e.g., airline offtake agreements), and availability of substitutes. It is also possible that a synergy would exist whereby demand and/or incentives for diesel or gasoline would result in jet fuel production as part of the product slate. Although this dynamic was not explored in this study, it will be explored in future analyses.

\footnotetext{
${ }^{7}$ Multi-cropping of winter crops in the Corn Belt could increase the supply of oils but such an analysis was outside the considerations of the current study (Winchester et al. 2013).

8 The catalytic upgrading of sugars and alcohol to jet processes are also consuming very limited amounts of herbaceous feedstocks in order to satisfy their offtake agreements.

9 The technical maximum amount of bio-jet possible was taken for each pathway.
} 


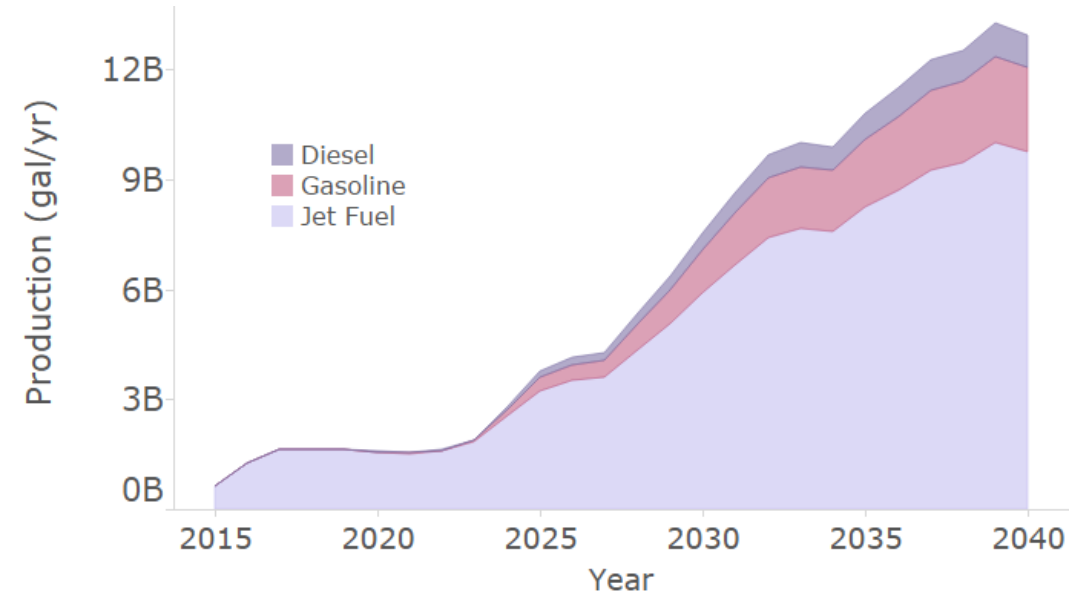

Figure 5. Finished fuel production in the case with a $\$ 60 /$ tonne carbon tax and a $\$ 1 /$ gal production incentive for jet fuel in addition to DMT investment and eight offtake agreements (see panel [m] in Figure 3) 


\section{Potential Emission Reductions}

To estimate the life-cycle GHG emissions associated with the BSM scenarios, the GHG intensities of biofuels, biomass feedstocks, and petroleum fuels were estimated using the Greenhouse Gases Regulated Emissions and Energy use in Transportation (GREET) model (Argonne National Laboratory 2016). Note that the energy mixes (e.g., electricity generation mix and shale gas production share) change over time and affect the GHG intensities of feedstocks and fuels, as they are inputs to many processes associated with the life-cycle production of these commodities. To account for the annual changes in the energy mix, the projections in AEO 2015 were used for GHG intensity calculation by GREET (Energy Information Administration 2015).

The GHG intensities of biofuel and feedstock production estimated by GREET were multiplied by the biofuel production and feedstock demands estimated by BSM, which results in the overall GHG emissions from the biofuel development. It was assumed that the produced biofuels would displace corresponding petroleum fuels on an energy basis. For example, one megajoule of ethanol or renewable gasoline would displace one megajoule of petroleum gasoline. The GHG emissions of displaced petroleum fuels (i.e., gasoline, diesel, and jet) were calculated by multiplying the amount of the displaced petroleum fuels by the life-cycle GHG intensities of the petroleum fuels. In addition, it was assumed that (1) the herbaceous energy crop would be a mix of $50 \%$ switchgrass and $50 \%$ Miscanthus on a dry mass basis and (2) the woody energy crop would be a mix of $50 \%$ willow and $50 \%$ poplar on a dry mass basis. The GHG intensities of FTJ, HEFA, and petroleum jet were estimated to be 14-16, 30-31 and 85-86 grams of CO2 equivalent per megajoule, respectively. It should be noted that carbon neutrality for biogenic carbon is assumed to calculate the GHG intensities of biofuels. While carbon neutrality for biomass with a short carbon cycle (e.g., annual crops and perennial plants) is established, that with a long carbon cycle (e.g., long-lived woody biomass) is a subject of ongoing debate. Detailed discussion about the GHG intensity of FTJ, HEFA, and petroleum jet can be found in Han et al. (2013) and Elgowainy et al. (2014).

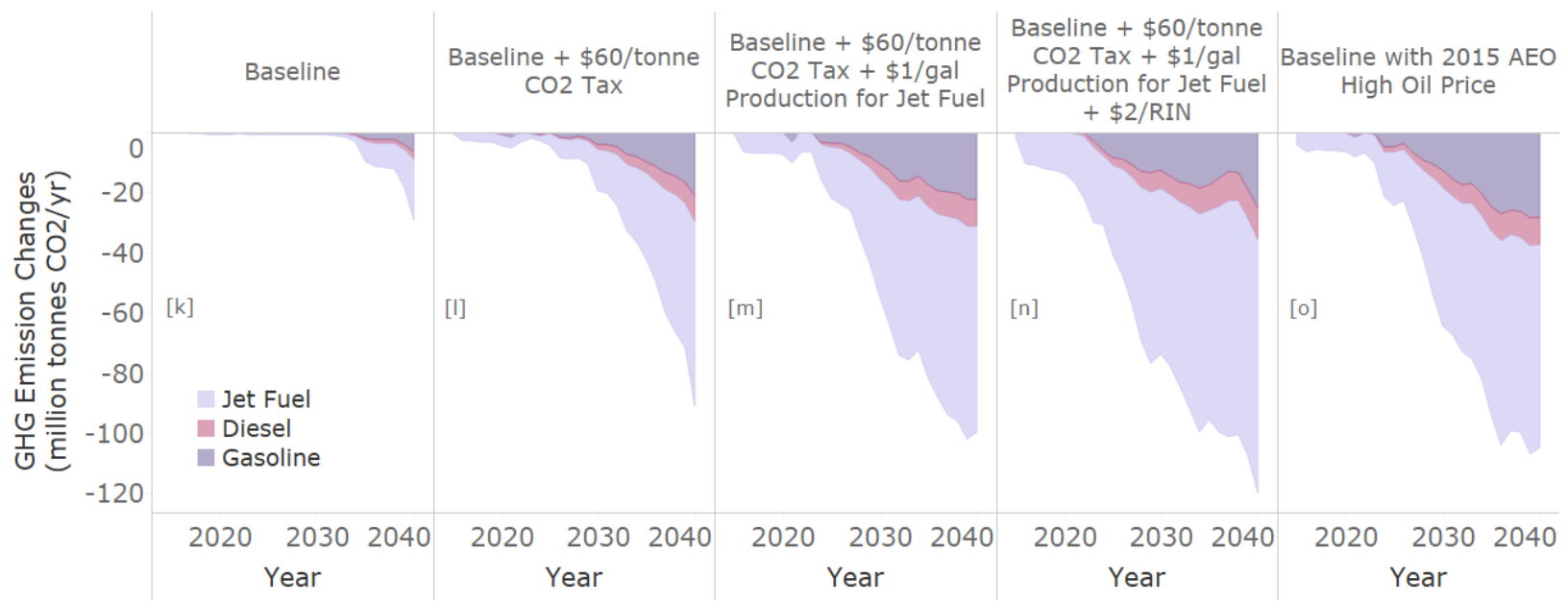

Figure 6. GHG emissions changes by renewable fuels in million tonnes $\mathrm{CO}_{2} \mathrm{e} / \mathrm{year}$ with DMT investment and eight offtake agreements relative to the reference scenario (the baseline scenario with no offtake agreements of DMT investment) (Figure 3, Row 3 compared with panel [a]) 
To estimate the impacts on the GHG emissions of the public/private investment scenarios, the baseline scenario with no offtake agreement or DMT investment was selected as a reference scenario (Figure 3, panel [a]). Then, the GHG emissions changes by renewable fuels (i.e., ethanol, gasoline, diesel, and jet) with DMT investment and eight offtake agreements (Figure 3, Row 3) relative to the reference scenario were calculated as shown in Figure 6. With no additional incentives other than the DMT investment and eight offtake agreements, the incremental annual GHG emissions reduction could reach approximately 29 million tonnes $\mathrm{CO}_{2} \mathrm{e}$ in 2040. And, the increased incentives could increase the incremental annual GHG emissions reduction to the range of 91 (\$60/tonne carbon tax), $99(\$ 60 /$ tonne carbon tax and $\$ 1 /$ gal production incentive for jet fuel) and 120 (\$60/tonne carbon tax, $\$ 1 /$ gal production incentive for jet fuel and \$2/RIN) million tonnes $\mathrm{CO}_{2} \mathrm{e}$ in 2040. Using oil prices from AEO 2015 High Oil Price Case, the incremental annual GHG emissions reduction is simulated at approximately 105 million tonnes $\mathrm{CO}_{2} \mathrm{e}$ in 2040.

Because the study maximized jet fuel production, the GHG emissions results were dominated by those associated with jet fuels. For example, with $\$ 60 /$ tonne carbon tax and $\$ 1 /$ gal production incentive for jet fuel (Figure 3, panel [m]), the annual GHG emissions reductions in 2040 by gasoline, diesel, and jet were on the order of 22, 9, and 68 million tonnes $\mathrm{CO}_{2} \mathrm{e}$, respectively. The jet fuel's GHG emissions reductions of approximately 68 million tonnes $\mathrm{CO}_{2} \mathrm{e}$ is equivalent to $25 \%$ of total GHG emissions from jet fuel consumptions projected by AEO 2015 (276 million tonnes $\mathrm{CO}_{2} \mathrm{e}$ ).

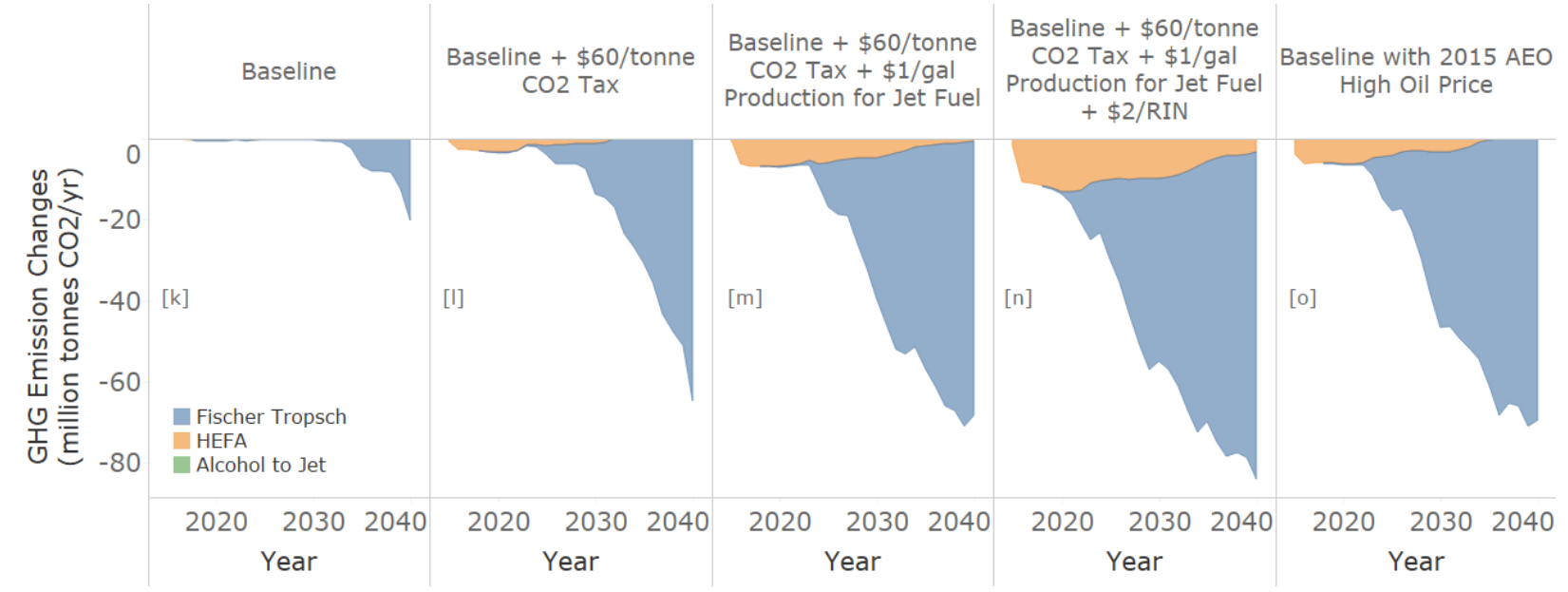

Figure 7. GHG emissions changes by ATJ, HEFA, and FTJ in million tonnes $\mathrm{CO}_{2} \mathrm{e} /$ year with DMT investment and eight offtake agreements relative to the reference scenario (the baseline scenario with no offtake agreements of DMT investment) (Figure 3, Row 3 compared with panel [a]) 
Figure 7 (previous page) presents the GHG emissions changes by each renewable jet fuel (ATJ, HEFA, and FTJ) with DMT investment and eight offtake agreements (Figure 3, Row 3) relative to the reference scenario (Figure 3, panel [a]). The figure shows that FTJ is the largest contributor to the incremental jet fuel GHG emissions reductions, which results from the large incremental volume of FTJ production ${ }^{10}$ and the low GHG intensity of FTJ.

\footnotetext{
${ }^{10}$ FTJ has the highest levels of production because it is the most mature cellulosic hydrocarbon technology and because it receives loan guarantees and offtake agreements, which give it a comparative advantage for outcompeting other technologies.
} 


\section{Conclusions}

This study explores the biomass-to-biofuels system in the context of possible policy and investment strategies to promote the production of aviation biofuels. Numbers presented should not be considered predictive. Our results suggest a significant penetration (six billion gallons $-30 \%$ of U.S. demand) of aviation biofuels by 2030 could be possible under aggressive policy and/or investment scenarios, but various factors related to policy design (in the absence of high oil prices and policy uncertainty) contribute to the timing and magnitude of aviation biofuels production:

- Incentives targeted toward jet fuel production, such as financial incentives (e.g., a producer tax credit or a carbon tax) could be sufficient to reach six billion gallons.

- Investment in pre-commercial technologies is needed to reduce the cost of production through learning-by-doing.

- Reduction of investment risk through loan guarantees and offtake agreements may allow production to ramp up more quickly through accelerating industry learning.

In cases with high levels of incentives and investment in aviation biofuels, there could be a $25 \%$ reduction in overall GHG emissions from the aviation sector.

Aviation biofuels are more competitive in scenarios with high oil price assumptions than those with reference price assumptions. For this analysis, the refinery split between aviation biofuels and renewable diesel, and their potential synergies, was not dynamically determined. Because this dynamic could play a large role in whether aviation biofuels will take off, it will be explored in future analyses. 


\section{References}

Aeronautics Science and Technology Subcommittee. 2016. "Federal Alternative Jet Fuels Research and Development Strategy." Washington, DC: National Science and Technology Council.

https://www.whitehouse.gov/sites/default/files/federal_alternative_jet_fuels_research_an d_development_strategy.pdf.

Air Transport Action Group. 2010. "Flightpath Set for Cancun." Green Flight Times, November, 4th edition. www.atag.org/component/downloads/downloads/71.html.

— 2015. "Aviation Climate Solutions." Geneva, Switzerland: Air Transport Action Group. http://aviationbenefits.org/media/125796/Aviation-Climate-Solutions_WEB.pdf.

Argonne National Laboratory. 2016. "GREET1 Model 2015 [WWW Document]." http://greet.es.anl.gov/.

Bureau of Transportation Statistics. 2015. "Table 4-21: Energy Intensity of Certificated Air Carriers, All Services(a)." National Transportation Statistics. October 27. http://www.rita.dot.gov/bts/sites/rita.dot.gov.bts/files/publications/national_transportation statistics/html/table_04_21.html.

Bush, Brian. 2015. "Biomass Scenario Model." presented at the Bioenergy Technologies Office Peer Review, Washington, DC, March 24. http://www.energy.gov/sites/prod/files/2015/04/f22/sustainability_and_strategic_analysis bush_4121_0.pdf.

Clark, Christopher, Yolanda Lin, Britta Bierwagen, Laurence Eaton, Matthew Langholtz, Philip Morefield, Caroline Ridley, Laura Vimmerstedt, Steve Peterson, and Brian Bush. 2013. "Growing a Sustainable Biofuels Industry: Economics, Environmental Considerations, and the Role of the Conservation Reserve Program." Environmental Research Letters 8 (2): 25016. doi:10.1088/1748-9326/8/2/025016.

Davidson, Carolyn, Emily Newes, Amy Schwab, and Laura Vimmerstedt. 2014. “An Overview of Aviation Fuel Markets for Biofuels Stakeholders.” NREL/TP-6A20-60254. Golden, CO: National Renewable Energy Laboratory. http://www.nrel.gov/docs/fy14osti/60254.pdf.

Davis, Ryan, Ling Tao, Christopher Scarlata, Eric Tan, Jeff Ross, John Lukas, and Danielle Sexton. 2015. "Process Design and Economics for the Conversion of Lignocellulosic Biomass to Hydrocarbons: Dilute-Acid and Enzymatic Deconstruction of Biomass to Sugars and Catalytic Conversion of Sugars to Hydrocarbons." http://www.nrel.gov/docs/fy15osti/62498.pdf.

Davis, Ryan, Ling Tao, Eric Tan, Mary Biddy, Gregg Beckham, Christopher Scarlata, Jake Jacobson, et al. 2013. "Process Design and Economics for the Conversion of Lignocellulosic Biomass to Hydrocarbons: Dilute-Acid and Enzymatic Deconstruction of Biomass to Sugars and Biological Conversion of Sugars to Hydrocarbons." http://www.nrel.gov/docs/fy14osti/60223.pdf.

Elgowainy, Amgad, Jeongwoo Han, Hao Cai, Michael Wang, Grant Forman, and Vincent DiVita. 2014. "Energy Efficiency and Greenhouse Gas Emission Intensity of Petroleum Products at U.S. Refineries." Environmental Science \& Technology 48 (13): 7612-24. doi:10.1021/es5010347.

Energy Information Administration. 2015. "Annual Energy Outlook 2015." Analysis \& Projections. April 14. http://www.eia.gov/forecasts/archive/aeo15/. 
GE Aviation. 2013. "GE Aviation Pursues Alternative Fuel Sources for Its Jet Engine Testing." Other Releases. November 6.

http://www.geaviation.com/press/other/other_20131106.html.

Gevo Inc. 2016a. “ASTM Completes Revision of Standard Specification.” GlobeNewswire News Room. April 12. http://globenewswire.com/newsrelease/2016/04/12/827983/0/en/ASTM-Completes-Revision-of-StandardSpecification.html.

- 2016b. "Gevo Signs Heads of Agreement with Lufthansa for Commercial Supply of Renewable Jet Fuel." Investor Relations. September 7. http://ir.gevo.com/phoenix.zhtml?c=238618\&p=RssLanding\&cat=news\&id=2200139.

Gulfstream Corporation. 2015. "Gulfstream And World Fuel Sign Renewable Fuels Agreement." May 18. http://www.prnewswire.com/news-releases/gulfstream-and-world-fuel-signrenewable-fuels-agreement-300084249.html.

Han, Jeongwoo, Amgad Elgowainy, Hao Cai, and Michael Wang. 2013. "Life-Cycle Analysis of Bio-Based Aviation Fuels.” Bioresource Technology 150 (December): 447-56. doi:10.1016/j.biortech.2013.07.153.

Haq, Zia. 2015. "Biofuels in Defense, Aviation and Marine.” presented at the Bioenergy Technologies Office Peer Review, Washington, DC, March 24. http://www.energy.gov/sites/prod/files/2015/04/f21/day_2_plenary_haq_aviation.pdf.

International Air Transport Association. 2016. "Alternative Fuels." Fact Sheet. Montreal, Canada: International Air Transport Association.

https://www.iata.org/pressroom/facts_figures/fact_sheets/Documents/fact-sheetalternative-fuels.pdf.

International Civil Aviation Organization. 2016a. "Carbon Offsetting and Reduction Scheme for International Aviation (CORSIA)." Global Market-Based Measure (CORSIA). September 9. http://www.icao.int/environmental-protection/Pages/market-based-measures.aspx. . 2016b. "Historic Agreement Reached to Mitigate International Aviation Emissions." News Releases. October 6. http://www.icao.int/Newsroom/Pages/Historic-agreementreached-to-mitigate-international-aviation-emissions.aspx.

isee systems. 2016. "Stella." Products. http://www.iseesystems.com/store/products/.

KLM. 2016. "KLM to Operate Biofuel Flights out of Los Angeles." Newsroom. September 8. http://news.klm.com/klm-to-operate-biofuel-flights-out-of-los-angeles.

Lane, Jim. 2014. "US Navy, DOE, USDA Award \$210M for 3 Biorefineries and Mil-Spec Fuels : Biofuels Digest." September 19. http://www.biofuelsdigest.com/bdigest/2014/09/19/breaking-news-us-navy-doe-usdaaward-210m-for-3-biorefineries-and-mil-spec-fuels/.

National Academies of Sciences, Engineering, and Medicine. 2016. Commercial Aircraft Propulsion and Energy Systems Research: Reducing Global Carbon Emissions. Washington, DC: The National Academies Press. https:/www.nap.edu/catalog/23490/commercial-aircraft-propulsion-and-energy-systemsresearch-reducing-global-carbon.

National Resources Conservation Service. 2016. "USDA Farm Production Regions." http://www.nrcs.usda.gov/wps/PA_NRCSConsumption/download?cid=stelprdb1048013 \&ext $=$ pdf. 
Newes, Emily, Brian Bush, Corey Peck, and Steven Peterson. 2015. "Potential Leverage Points for Development of the Cellulosic Ethanol Industry Supply Chain." Biofuels 6 (1-2): 2129. doi: $10.1080 / 17597269.2015 .1039452$.

Newes, Emily, Daniel Inman, and Brian Bush. 2011. "Understanding the Developing Cellulosic Biofuels Industry through Dynamic Modeling." In Economic Effects of Biofuel Production, edited by Marco Aurélio dos Santos Bernardes, 373-404. Rijeka, Croatia: InTech. http://www.intechopen.com/books/economic-effects-of-biofuelproduction/understanding-the-developing-cellulosic-biofuels-industry-through-dynamicmodeling.

Pearlson, Matthew, Christoph Wollersheim, and James Hileman. 2013. "A Techno-Economic Review of Hydroprocessed Renewable Esters and Fatty Acids for Jet Fuel Production." Biofuels, Bioproducts and Biorefining 7 (1): 89-96. doi:10.1002/bbb.1378.

Schlangenstein, Mary. 2016. "JetBlue to Burn Renewable Biofuel Mix on Some New York Flights." Bloomberg.com, September 19. http://www.bloomberg.com/news/articles/201609-19/jetblue-to-burn-renewable-biofuel-mix-on-some-new-york-flights.

Schwab, Amy, Ethan Warner, and John Lewis. 2016. "2015 Survey of Non-Starch Ethanol and Renewable Hydrocarbon Biofuels Producers." http://www.nrel.gov/docs/fy16osti/65519.pdf.

Steele, Paul. 2016. "Environment... Unpacking ICAO and Unruly Passengers." presented at the Media Day 2016. http://www.iata.org/pressroom/media-kit/Documents/corsia-unrulypax-gmd16.pdf.

Sterman, John, J. Bradley Morrison, and Nelson Repenning. 2003. "System Dynamics for Business Policy." Sloan School of Management | MIT OpenCourseWare. https://dspace.mit.edu/bitstream/handle/1721.1/91162/15-874-fall2003/contents/index.htm.

Tan, Eric, Lesley Snowden-Swan, Michael Talmadge, Abhijit Dutta, Susanne Jones, Karthikeyan Ramasamy, Michel Gray, et al. 2016. "Comparative Techno-Economic Analysis and Process Design for Indirect Liquefaction Pathways to Distillate-Range Fuels via Biomass-Derived Oxygenated Intermediates Upgrading." Biofuels, Bioproducts and Biorefining, September, n/a-n/a. doi:10.1002/bbb.1710.

UOP. 2008. "UOP/ENI Ecofining Process Cut Sheet."

U.S. Federal Aviation Administration. 2013. "FAA Awards $\$ 40$ Million to New Center of Excellence.” Template. Press Release. September 13. https://www.faa.gov/news/press releases/news_story.cfm?newsId=15114.

Vimmerstedt, Laura, Brian Bush, Dave Hsu, Daniel Inman, and Steven Peterson. 2015. "Maturation of Biomass-to-Biofuels Conversion Technology Pathways for Rapid Expansion of Biofuels Production: A System Dynamics Perspective." Biofuels, Bioproducts and Biorefining 9 (2): 158-76. doi:10.1002/bbb.1515.

Vimmerstedt, Laura, Brian Bush, and Steve Peterson. 2012. "Ethanol Distribution, Dispensing, and Use: Analysis of a Portion of the Biomass-to-Biofuels Supply Chain Using System Dynamics." PLoS ONE 7 (5): e35082. doi:10.1371/journal.pone.0035082. . 2013. "Effects of Deployment Investment on the Growth of the Biofuels Industry." Technical Report. Golden, Colorado: National Renewable Energy Laboratory. http://dx.doi.org/10.2172/1118095. 
Vimmerstedt, Laura, Ethan Warner, and Dana Stright. 2016. "Effects of Deployment Investment on the Growth of the Biofuels Industry: 2016 Update." Technical Report NREL/TP6A20-65903. Golden, Colorado: National Renewable Energy Laboratory. http://www.nrel.gov/docs/fy16osti/65903.pdf.

Wang, Wei-Cheng, Ling Tao, Jennifer Markham, Yanan Zhang, Eric Tan, Liaw Batan, Ethan Warner, and Mary Biddy. 2016. "Review of Biojet Fuel Conversion Technologies." http://www.nrel.gov/docs/fy16osti/66291.pdf.

Warner, Ethan. Memo to Laura Vimmerstedt. 2014. "Limits to Annual Growth in the Number of Biorefineries - Analysis of Existing Literature and Development of Biomass Scenario Assumptions," January 19. 